LOGI - Scientific Journal on Transport and Logistics

Vol. $11 \quad$ No. $2 \quad 2020 \quad$ DOI: 10.2478/logi-2020-0021

(C) 2020 F. Bădău et al. This is an open access article licensed under the Creative Commons Attribution-Non Commercial-No Derivs License (http://creativecommons.org/licenses/by-nc-nd/3.0/).

\title{
Management of Urban and Regional Rail: Case Study Bucharest
}

\author{
Florin Bădău ${ }^{1 *}$, Borna Abramović ${ }^{2}$, Angel Ciprian Cormoș ${ }^{1}$ and Valentin Iordache ${ }^{1}$ \\ ${ }^{1}$ Politehnica University of Bucharest, Faculty of Transports, Department of Telematics and \\ Electronics for Transport, Splaiul Independenței 313, 060042 Bucharest, Romania; Email: \\ florin.badau@upb.ro,angel.cormos@upb.ro,valentin.ioradche@upb.ro \\ ${ }^{2}$ University of Zagreb, Faculty of Transport and Traffic Sciences, Department of Railway \\ Transport, Vukelićeva 4, 10000 Zagreb, Croatia; Email: borna.abramovic@fpz.hr
}

\section{*Corresponding Author: Florin Bădău}

Received: 29 October 2020; Revised: 7 November 2020; Accepted: 14 November 2020; Published: 30 November 2020

\begin{abstract}
The capital of Romania is the main railway hub of the country. As such, the railway network around the capital is quite extensive, with main cities around it being directly connected by rail. Despite this, there are no regular train services for commuters, similar to other large European cities. This paper aims to analyze the current state of railway passenger transport in the region surrounding Bucharest, to highlight the weaknesses of the network and to present a guideline for the implementation of an efficient commuter service. 100 stations in and around the city were evaluated with regard to their degree of accessibility (DoA), defined as the location of the station relative to the nearest settlement. Train frequency, travel times and journey costs were determined for each line originating in Bucharest. These variables were compared to their road equivalents to highlight the differences between these two modes of transport. Low train frequency and the remoteness of many stations were determined to be the main obstacles in establishing an appropriate commuter service. Reworking future timetables to prioritize commuter trains is proposed as a short-term solution, while line improvements and better integration with existing public transport are set as priorities.
\end{abstract}

Keywords: Urban rail network, railway commuters, rail network analysis, train frequency, regional rail

\section{Introduction}

Bucharest is the capital and biggest city in Romania with an estimated population of 1.827 .810 inhabitants in 2018 [1]. Like any large and modern city, Bucharest has an extensive public transport network made up of different elements. 
The Bucharest Metro, spread over four lines with a total length of $71.35 \mathrm{~km}$, is the backbone of the system. The tram network is the next most crucial part of the transport system and totals a length of $147 \mathrm{~km}$ of a double with 26 different lines [2]. Over 100 bus lines run inside Bucharest, together with 15 trolleybus lines [3].

The 2016 - 2030 Durable Urban Mobility Plan (DUMP) analysed and proposed methods of connecting the suburbs of Bucharest with the city. An important proposal was the establishment of 58 new regional bus lines [4], of which currently (May 2019) over half (38) are operational.

Other vital proposals regarded the administration of different transport operators within Bucharest and the surrounding Ilfov county. As the result of this, in 2018, the Intercommunal Development Association for Public Transport Bucharest - Ilfov (IDAPBI) was established as the sole regulatory and managing legal entity over public transport in this region [5]. Currently, this association does not include underground or rail transport.

Despite being the main hub of the Romanian rail network, Bucharest does not have regular commuter train services like other European cities (German and Austria S-Bahn, French RER). This document aims to analyse the current state of railway passenger transport in Bucharest and the surrounding region and to propose solutions for improving mobility.

\section{Current State of Railways in and around Bucharest}

The first railway line in Bucharest opened in 1869 and connected the city with the Danube city of Giurgiu. Over the years, the rail network has changed massively, with new lines being built in and around the city and with older lines being decommissioned. The current network topology is best described as a railway ring which encloses the city with seven railway branches radiating from within the city, five of which have a common origin point in the north-west part of the city (Fig. 1).

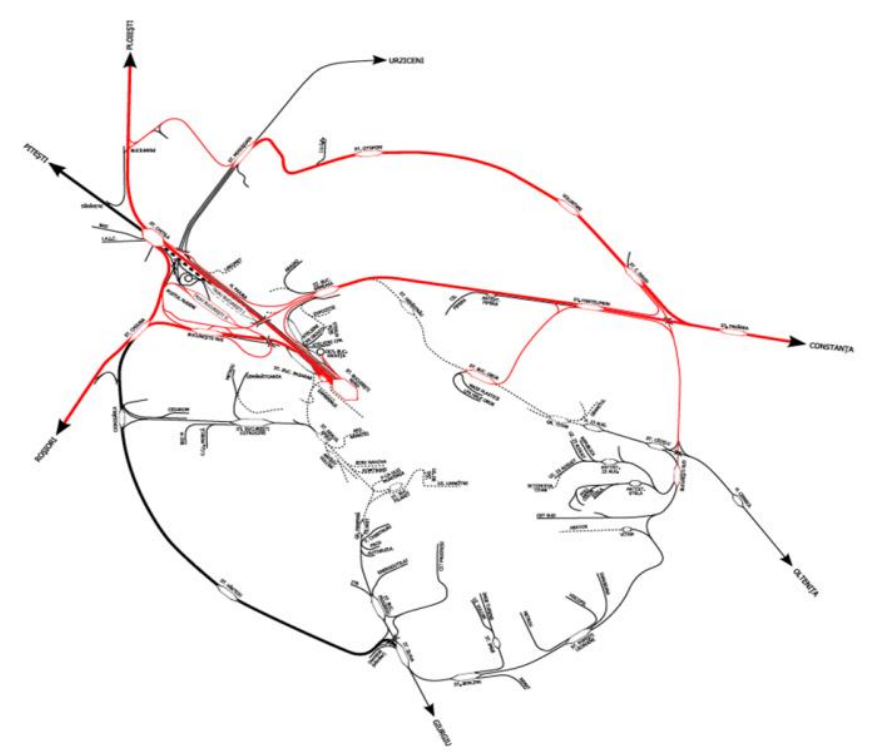

Black: non-electrified, Red: electrified, Thin: simple track; Thick: double or multi-track, Dotted: decommissioned track.

Fig. 1 Overview of the rail network in and around Bucharest. Source: [6] 


\subsection{Railway Stations in Bucharest}

Bucharest has within its administrative borders ten train stations, half of which are terminus stations with the most passenger traffic.

\subsubsection{Bucharest North (București Nord)}

This has long been the main station of Bucharest and the largest rail station in Romania with 14 tracks and eight platforms. All international and intercity connections terminate here. The historical building of the station needs rehabilitation, and the station must be reconfigured to meet current transport standards. There have been several initiatives over the last few years regarding the reconstruction of the station, none of which have materialised in an actual project [6-9]. The station is connected to metro lines 1 and 4 and four tram lines.

\subsubsection{Bucharest Basarab (București Basarab)}

With the increase of rail traffic after the Second World War, it was increasingly more challenging for Bucharest North railway station to accommodate all trains. As a solution, Bucharest Basarab station was built in 1959 not far from it. The station has three tracks and two platforms. Currently, only regional trains use this station (11 departures and 17 departures per day) [10-12]. The station is connected to metro lines 1 and 4 and to four tram lines.

\subsubsection{Bucharest Obor/East (București Obor/Est)}

It is the second-largest railway station in Bucharest and is in the North-East of the city. There are three tracks used for passenger transport and two unused tracks. Only regional trains use this station ( 7 pairs of trains per day) $[13,14]$. The station only has bus connections, but there is an unused tram track that runs to the station.

\subsubsection{Titan South (Titan Sud)}

This small station lies in the East of Bucharest and has only two tracks. It is only used by the private operator TFC. The station is connected to metro line 1 and to two tram lines.

\subsubsection{Bucharest Progresul (București Progresul)}

The southern station of Bucharest has three tracks. No passenger trains run through this station since 2005 when a bridge on the mainline to Giurgiu collapsed. The station has regular bus service, and an end station for two tram lines lies in its vicinity. 


\subsubsection{Bucharest Băneasa (București Băneasa)}

The station lies on the main rail corridor running to Constanța on the Black Sea. It has three tracks with two platforms. Traditionally used as a protocol station, it sees only four pairs of trains per day. The station does not have any connections. There is a bus stop nearby and a station on the future metro line 6 will be built here [15-18].

\subsection{Railway Stations around Bucharest}

To evaluate railway passenger transport around Bucharest, we considered all stations within a radius of approximately $60 \mathrm{~km}$ for analysis. What was important was to record how many people lived around the train stations and how easily accessible they were. The stations were organized into four categories based on their position in relationship to the nearby settlements, as shown in Fig. 2.

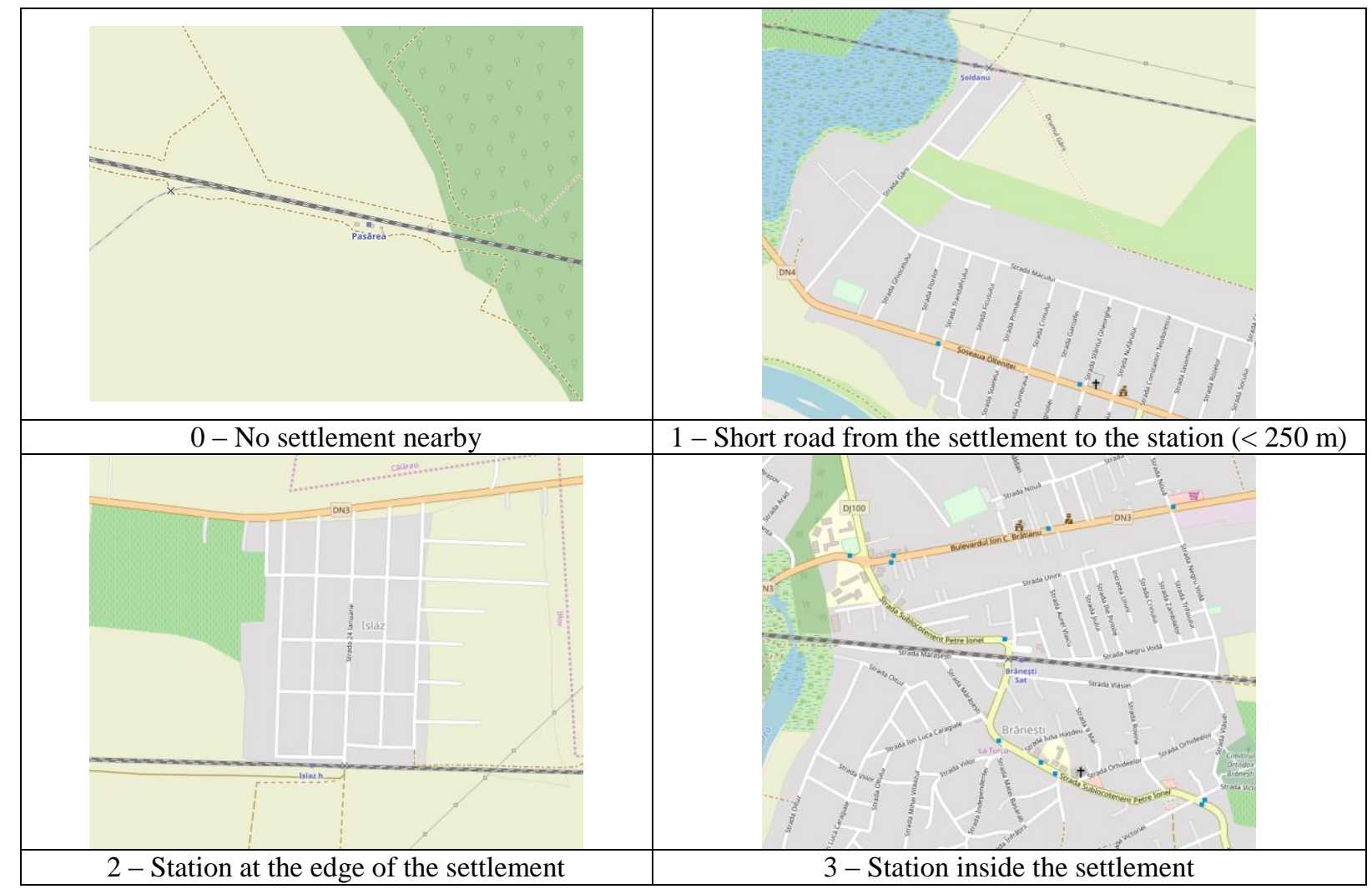

Fig. 2 Defining the degree of accessibility (DoA) of railway stations. Source: authors

Third-degree stations have the best position and are accessible to most people in the settlement. Second-degree stations will be used by people living on the same side of the settlement or by the whole settlement depending on its size. First degree stations will not see much use, except by the people living closest to it. Other transport to the station may be necessary (ex: bus service). Zeroth degree stations are far from any point of interest and will have low to no passenger demand. A better classification would be possible with access to the data from the station manager.

All the collected data is presented in 0 
Table 1 Characteristic of each station. Source: authors

\begin{tabular}{|c|c|c|c|c|c|c|c|c|}
\hline Station & Pop. & DoA & Station & Pop. & DoA & Station & Pop. & DoA \\
\hline Anghelesti & & 0 & Daia & & 0 & Peris & 5600 & 2 \\
\hline Armasesti & & 0 & Dambovicioara & 1200 & 2 & Plataresti & 1700 & 2 \\
\hline Baldana & 2000 & 1 & Darza & 2000 & 1 & Ploiesti Sud & & 3 \\
\hline Balotesti & & 0 & Domnestii de Sus & 7900 & 2 & Ploiesti Triaj & & 0 \\
\hline Baneasa & 3200 & 1 & Dridu & 3100 & 1 & Ploiesti Vest & & 2 \\
\hline Banesti & 300 & 1 & Fierbinti & & 0 & PO Aeroport & & 0 \\
\hline Barbulesti & 5900 & 2 & Fratesti & 2500 & 3 & $\begin{array}{l}\text { Podu } \\
\text { Pitarului }\end{array}$ & 500 & 2 \\
\hline Boteni & 1000 & 2 & Frunzaresti & 5600 & 3 & Podul Rizii & & 0 \\
\hline Branesti & & 0 & Fundulea & 6800 & 1 & Prahova & 1100 & 1 \\
\hline Branesti Sat & 7300 & 3 & Galbinasi & 3700 & 2 & Preasna & 1200 & 2 \\
\hline Brazi & & 0 & Ghergani & 760 & 3 & Săbăreni & & 0 \\
\hline Buc Nord Gr.B (Basarab) & & 3 & Giurgiu & & 3 & Sarulesti & 1600 & 3 \\
\hline Bucuresti Baneasa & & 2 & Giurgiu Nord & & 1 & Scrovistea & & 0 \\
\hline Bucuresti Basarab H & & 2 & Gradinari & & 0 & Sintesti & 2900 & 2 \\
\hline Bucuresti Est (Obor) & & 3 & Gradistea & 1500 & 2 & Snagov & & 0 \\
\hline Bucuresti Nord Gr. A & & 3 & Greci & & 0 & Snagov Sat & & 0 \\
\hline Bucuresti Progresul & & 2 & Islaz & 1600 & 2 & Soldanu & 2400 & 1 \\
\hline Bucuresti Sud Gr. Calatori & & 1 & Jilava & & 1 & Tabanu & 500 & 2 \\
\hline Bucuresti Triaj & & 1 & Lehliu & 6500 & 3 & Tanganu & 3100 & 1 \\
\hline Bucurestii Noi & & 1 & Luica & & 0 & Targoviste & 79600 & 2 \\
\hline Budesti & 7300 & 3 & Moara Vlasiei & 4400 & 2 & Titan Sud & & 3 \\
\hline Buftea & 22200 & 2 & Mogosoaia & & 0 & Titu & 9600 & 3 \\
\hline Caciulati & & 0 & Moldoveni & 1200 & 2 & Urziceni & 15300 & 3 \\
\hline Caldararu & & 0 & Mostistea & 560 & 1 & Vacaresti & 3100 & 2 \\
\hline Carpati & & 2 & Movila Dambovita & 950 & 2 & Vadu-Lat & & 0 \\
\hline Cazaci & 650 & 1 & Negoiesti & 1100 & 2 & Valea Rosie & 1500 & 2 \\
\hline Chiajna & & 0 & Nucet & & 0 & Vasilati & 3600 & 3 \\
\hline Chitila & 14200 & 3 & Odaile & & 0 & Videle & 11500 & 2 \\
\hline Ciocanesti & & 0 & Oltenita & 24800 & 2 & Vidra & 3800 & 3 \\
\hline Comana & 2100 & 3 & Pajura & & 2 & Vlad Tepes & 1700 & 2 \\
\hline Contesti & & 0 & Pantelimon & & 0 & Zavestreni & & 0 \\
\hline Crivina & 330 & 1 & Pantelimon Sud & & 3 & Zorile & 1100 & 2 \\
\hline Cucuieti Suditi & 700 & 2 & Parc Mogosoaia & 7600 & 2 & & & \\
\hline Curcani & 5600 & 2 & Pasarea & & 0 & & & \\
\hline
\end{tabular}

Note: Population missing from the station with 0-degree accessibility and stations within Bucharest, Ploiești and Giurgiu. Red text is for inactive stations. 


\subsection{Railway Lines around Bucharest}

Because Bucharest is the main railway hub of Romania many main lines of the rail network cross here. The following is a list of all the lines originating in Bucharest with the official index of the line written in parenthesis [19]:

- București Nord - Ploiești Vest (M300),

- București Nord - Ploiești Sud (M500),

- București Nord - Urziceni (M700),

- București Obor - Lehliu (M800),

- Titan Sud - Oltenița (M801),

- București Nord - Videle (M900),

- București Nord - Titu (M901),

- București Nord - Târgoviște (M901/4),

- București Progresul - Giurgiu (M902).

To evaluate the current state of passenger transport on these lines we looked at the number of regional (R) and interregional (IR) trains on each line in a normal weekday (considering both directions) [20]. The cost of one journey was defined for regional trains as the fare for one full 2nd class ticket without seat reservation and for interregional trains as the fare for a full 2 nd class tickets with seat reservation (default choices). The maximum speed data was extracted from the driver's handbook for 2019, while the average speed is calculated from the existing data (namely by using the journey time and distance). Driving data was taken from Google Maps with driving times calculated as an average for a typical working day in the morning (8:00) between the two end stations. Fuel consumption per $100 \mathrm{~km}$ was set at $6 \mathrm{~L}$, and the price for $1 \mathrm{~L}$ of fuel at $5.89 \mathrm{RON}$ $[21,22]$.

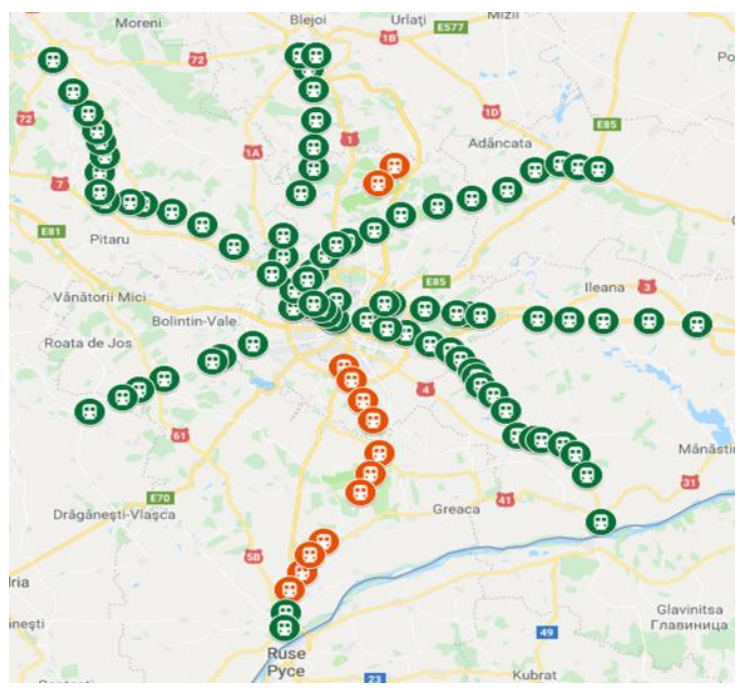

Fig. 3 Train stations in and around Bucharest (Green - operational, Orange - inactive). Source: authors 


\section{Data Analysis and Weak Points}

\subsection{Comparison of Road and Railway Transport}

Figures 4 and 5 illustrate the comparisons of two main variables regarding rail and road transport: travel time (Fig. 4) and travel cost (Fig. 5).

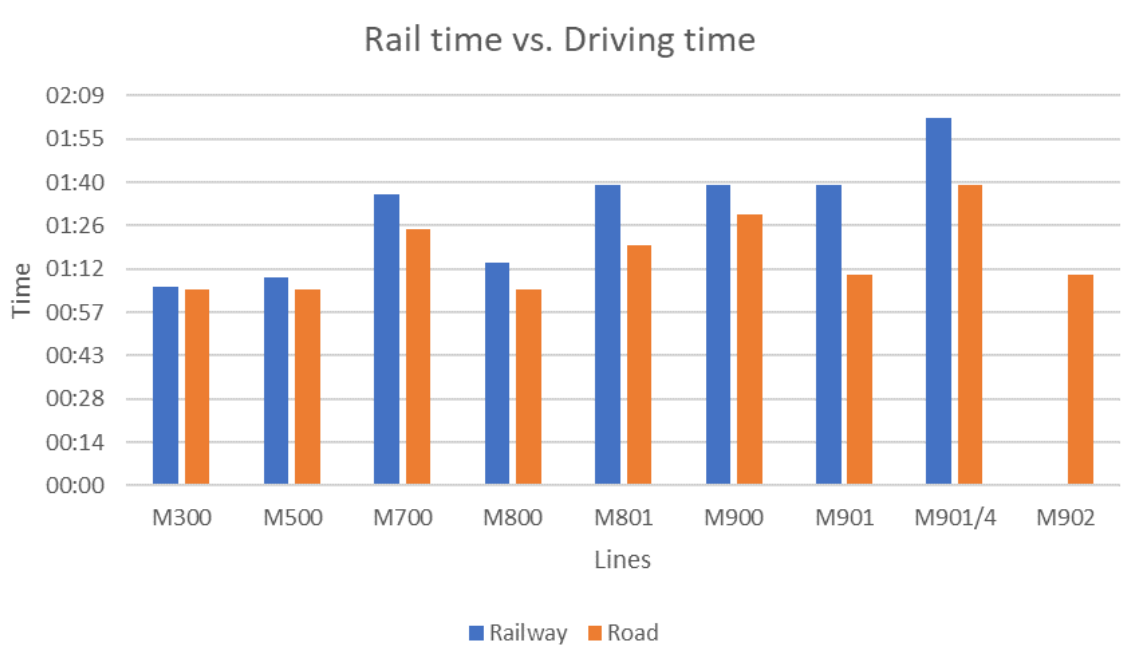

Fig. 4 Comparison of travel time between railways and roads. Source: authors

Regarding travel time, travelling by car is faster than taking the train. However, the time difference between the two is not very large, only of around 10 minutes $(1-4$ minutes on refurbished lines and a maximum difference of $30 \mathrm{~min}$ on M901) [23]. This slight advantage of road transport is offset by the cheaper price of rail travel (around 2.75 times cheaper). It can be concluded that current prices do not make train travel less attractive than road travel, quite the opposite [24].

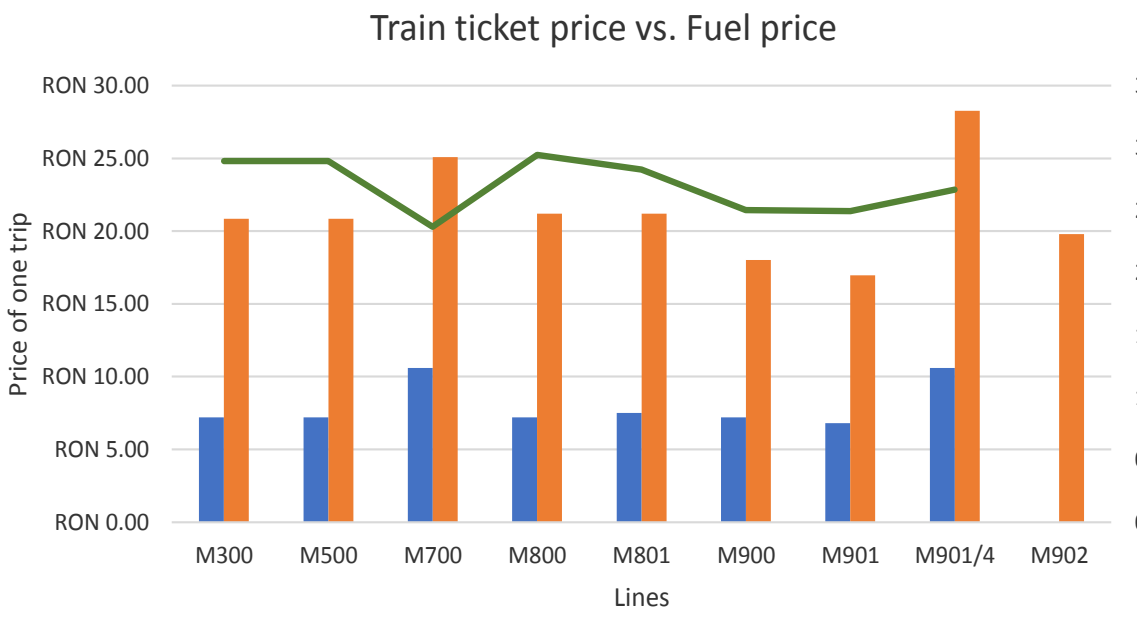

Fig. 5 Comparison of rail and train prices. Source: authors

\subsection{Analysis of Railways around Bucharest}

The first and most crucial problem for potential commuters is the low frequency of regional trains (Fig. 6), far below of what would be convenient to commuters ( $2-5$ trains/h depending on the time of day). 


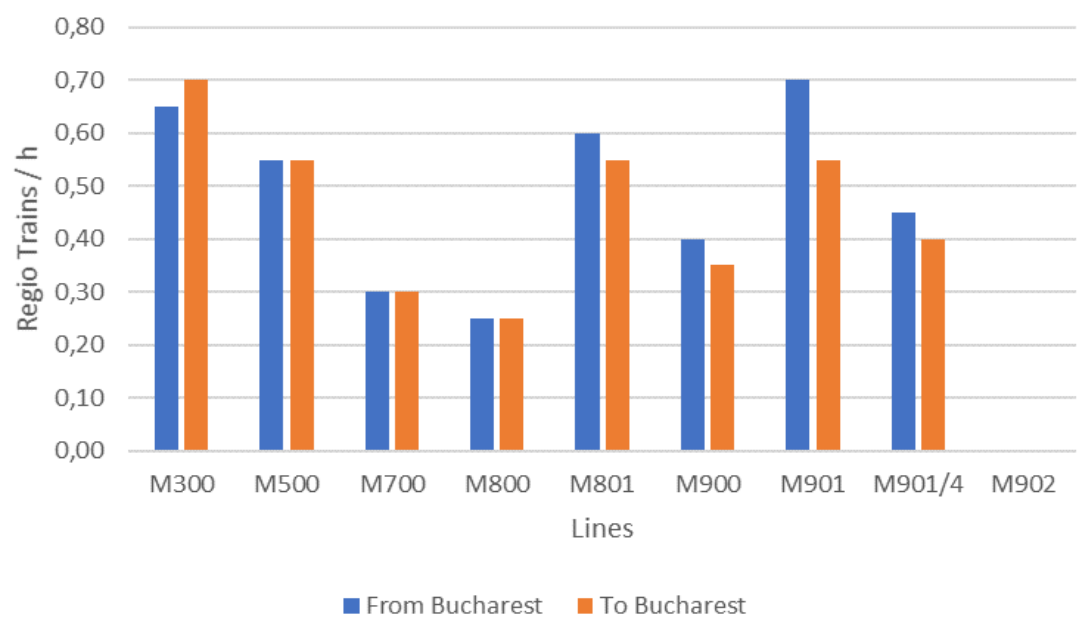

Fig. 6 Current frequency of Regio trains. Source: authors

The other factor deterring commuters is the position of many train stations. $30 \%$ of all analysed stations have a very low degree of accessibility (Fig. 7).

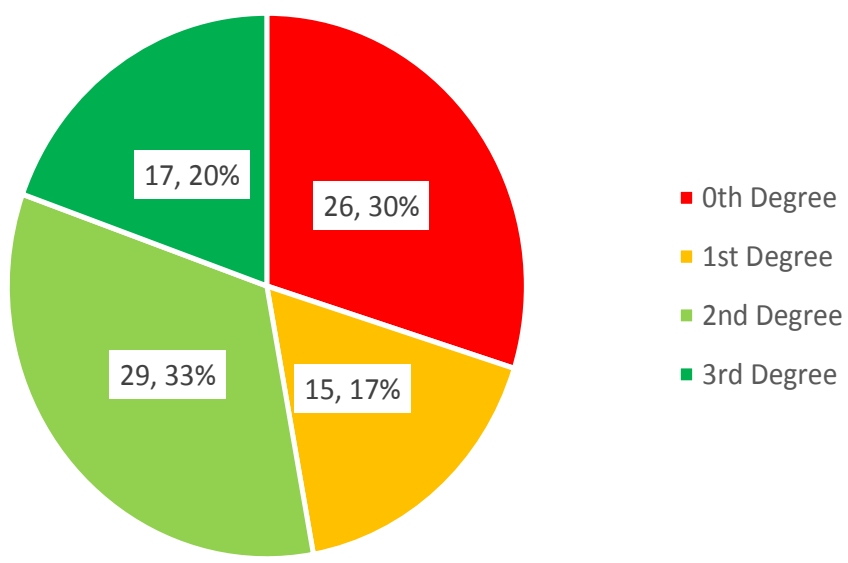

Fig. 7 Degree of accessibility for all stations. Source: authors

An overview of all stations on the analysed lines is presented in the chart below. This high number of inaccessible stations also affects the operation of trains. Trains that stop in these stations lose time and energy in exchange for a very low number of passengers [25].

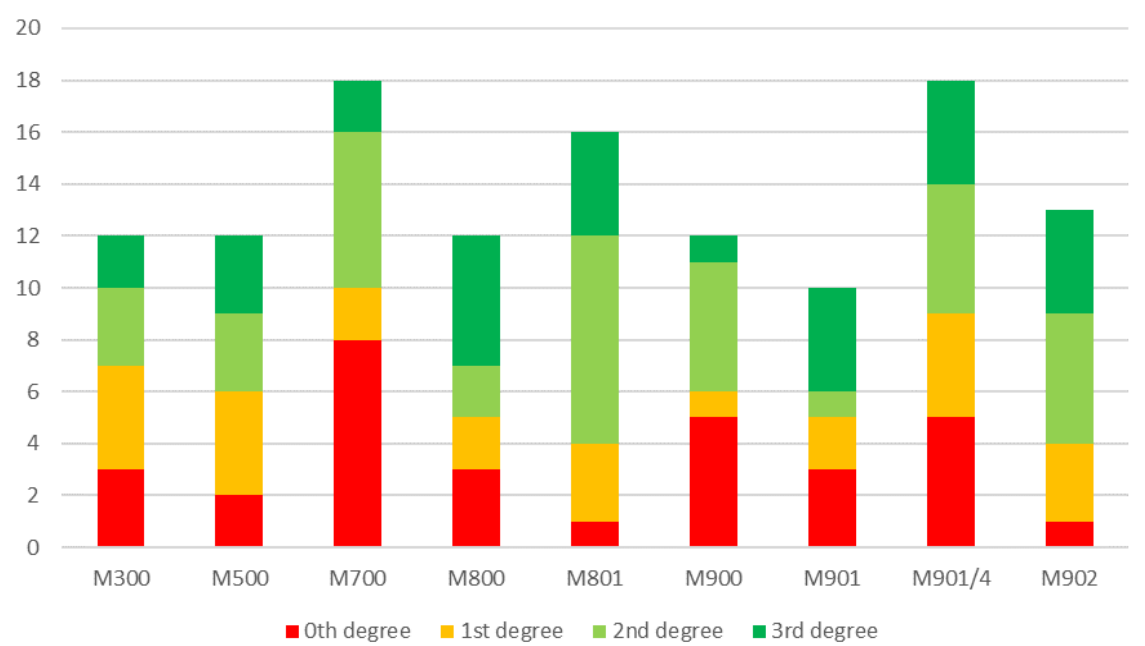

Fig. 8 Overview of accessibility on the lines around Bucharest. Source: authors 


\section{Discussion}

The railway system around Bucharest has the potential to support regular commuter services. However, this cannot happen without some profound changes. Any long-term plans must include overdue maintenance works on most of the lines and in most of the stations, as well as the acquisition of appropriate rolling stock. Short-term improvements may be made by restructuring the timetable to accommodate frequent train service [26].

This may prove problematic for lines with already high numbers of long-distance trains (ex: M300, M500). A solution may be to operate some longer distance R trains with local trains on the common line segment and then have them split (ex: Bucharest - Buzău R train may run together with the local train from Bucharest to Ploiești Sud, where they would split. The R train would run further to its destination, and the local train would return to Bucharest) [27].

Most stations with 0 degrees of accessibility should no longer be served by trains, at least for the foreseeable future. For stations with a $1^{\text {st }}$ degree of accessibility, local authorities should be approached to create more convenient connections to the station (ex: local bus service). This may also apply to some $0^{\text {th }}$ degree stations. Another critical aspect of regional transport that needs improving is ticketing. The new regional trains must be integrated with Bucharest's ticketing service. This system is based on contactless travel cards and would require stations or trains to be equipped with ticket validators [28]. Ticket machines would also need to be bought for all stations. This, combined with the ticket validators and with the maintenance, will imply a large initial investment. It is recommended for the system to be implemented line by line, not on the entire network at the same time [29].

\section{Conclusion}

Our analysis concludes that current train frequency and the remote location of many stations are among the main factors discouraging potential commuters. Even so, when looking at current travel times and journey costs, the train remains a viable alternative to the use of a personal vehicle. A short-term solution for making the train commute more attractive to travelers would be the reworking of the current timetable, so that commuter trains receive better and more regular timeslots. Further steps should also be taken by making the existing stations more accessible to nearby travelers and by integrating commuter trains with local public transport.

The results of the analysis offer a broad picture of the current state of regional rail transport around Bucharest. Future studies should however dive into more details if a more comprehensive overview of the current system is desired. One should seek to retrieve data regarding the number of passengers who use each station and passenger demand by time of day. Should this information not be publicly available, the local train operators should be requested to offer it. 


\section{References}

[1] TEMPO Online. (2018). Resident population (POP105A). Retrieved April 01, 2019, from http://statistici.insse.ro:8077/tempo-online/\#/pages/tables/insse-table.

[2] UrbanRail.Net > Europe > Romania > BUCHAREST Tram. (2019). Retrieved April 30, 2019, from http://www.urbanrail.net/eu/ro/buc/bucuresti-tram.htm.

[3] STB SA / Societatea de Transport Bucuresti STB SA. (2019). Retrieved April 30, 2019, from http://stbsa.ro/statistici.php.

[4] Rom Engineering Ltd, AVENSA Consulting SRL (2016). Durable Urban Mobility Plan 2016230 for the Bucharest-Ilfov Region. Retrieved April 01, 2019, from https://tpbi.ro/files/proiect_pmud.pdf.

[5] TPBI. (n.d.). General Informations. Retrieved April 30, 2019, from https://tpbi.ro/constituire

[6] Harta complex feroviar Bucureşti. (2008). Retrieved April 30, 2019, from https://transbuc.wordpress.com/2008/07/24/harta-complex-feroviar-bucuresti/.

[7] CAPITAL. (2012). The Romanian-Belgian company that will develop the North Railway Station will be founded in 2012. Retrieved April 30, 2019, from https://www.capital.ro/compania-romano-belgiana-care-va-dezvolta-gara-de-nord-va-fiinfiintata-in-2012-163936.html.

[8] Jurnalul.ro. (2016). The North Railway Station stays the same! Refurbishment costs exceed 200 million euros. Retrieved April 30, 2019 from: https://jurnalul.ro/stiri/observator/cfr-garade-nord-va-ramane-in-forma-care-este-costurile-pentru-reabilitare-depasesc-200-milioaneeuro-709739.html.

[9] Andrada Ghira. (2018). CEETRUS, member of the Auchan Group, will transform the North Railway Station in Paris by the end of 2024. It wants to do the same in Bucharest. Retrieved April 30, 2019, from www.economica.net website: https://www.economica.net/ceetrus--partedin-grupul-auchan--transforma-gara-de-nord-din-paris-pana-in-2024--acelasi-lucru-1-ar-puteaface-si-la-bucuresti_155960.html.

[10] INFOFER. (2019) Station departures/arrivals. Retrieved April 30, 2019, from https://mersultrenurilor.infofer.ro/ro-RO/Statie/Bucuresti-Basarab?Date=02.05.2019.

[11] INFOFER. (2019) Station departures/arrivals. Retrieved April 30, 2019, from https://mersultrenurilor.infofer.ro/ro-

$\mathrm{RO} /$ Stations? StationName=Bucure\%C8\%99ti+Obor\&Date=02.05.2019. 
[12] INFOFER. (2019) Station departures/arrivals. Retrieved April 30, 2019, from https://mersultrenurilor.infofer.ro/ro-

$\mathrm{RO} /$ Stations?StationName $=$ Bucure $\% \mathrm{C} 8 \% 99 \mathrm{ti}+\mathrm{B} \% \mathrm{C} 4 \% 83$ neasa $\&$ Date $=02.05 .2019$.

[13] INFOFER. (2019) Itineraries. Retrieved April 30, 2019, from https://mersultrenurilor.infofer.ro/ro-RO/Itineraries.

[14] Driver's Handbooks, rulebooks and other CFR documents. (2019). Retrieved April 30, 2019, from http://forum.peundemerg.ro/index.php?topic=1640.msg228252\#msg228252.

[15] Together on the Move (n.d.). Eco-driving Handout 6 Fuel consumption of cars Part 2a / Exercise 7. Retrieved April 30, 2019, from http://www.togethereu.org/docs/102/TOGETHER_Eco-driving_5_Handout_06.pdf.

[16] PECO ONLINE (n.d.). Fuel prices. Retrieved April 30, 2019, from https://www.pecoonline.ro

[17] Ziarul Financiar. (2004). End of railway upgrades between Bucharest and Campina. Retrieved May 3, 2019, from https://www.zf.ro/eveniment/final-la-modernizarea-rutei-feroviarebucuresti-campina-2945222.

[18] Club Feroviar. (2019). Authorities prepare a B plan for Euro 2020. The contract for the doubling of the railway line to the airport has been signed. Retrieved May 3, 2019 from https://clubferoviar.ro/planul-b-pentru-euro-2020/.

[19] Mobilitate.eu. (2019). CFR SA launches a tender for a feasibility study for the upgrade and maintenance works on multiple railway sections. Retrieved May 3, 2019 from https://mobilitate.eu/cfrsa-sf-modernizari-feroviare/.

[20] L'upták, V., Droździel, P., Stopka, O., Stopková, M. \& Rybicka, I. (2019). Approach Methodology for Comprehensive Assessing the Public Passenger Transport Timetable Performances at a Regional Scale. Sustainability 11(13), Article no. 3532. DOI: $10.3390 / \mathrm{su} 11133532$.

[21] Adevărul. (2019). Third time is the charm! The old flooded bridge and the new unfinished bridge will be demolished. A new one is built! Retrieved May 3, 2019 from https://adevarul.ro/economie/investitii/a-treia-oara-e-noroc-podul-vechi-inundat-nouneterminat-gradistea-vor-demolate-inca-unul-1_5c49ff23df52022f75f79ecb/index.htm.

[22] Club Feroviar. (2017). The contract for the feasibility study of the Bucharest-Giurgiu-Border section has been signed. Retrieved May 3, 2019 from https://clubferoviar.ro/planul-b-pentrueuro-2020/. 
[23] Fan, Y., Zhan, Q., Zhang, H. \& Wu, J. (2019). A Comprehensive Regional Accessibility Model Based on Actual Routes-of-ravel: A Proposal with Multiple Online Data. Lecture Notes in Geoinformation and Cartography, 463-482; In 16th International Conference on Computers in Urban Planning and Urban Management, CUPUM 2019, 8-12 July 2019 (Code 225999). Wuhan, China. DOI: 10.1007/978-3-030-19424-6_25.

[24] He, S.Y. (2020). Regional Impact of Rail Network Accessibility on Residential Property Price: Modelling Spatial Heterogeneous Capitalisation Effects in Hong Kong. Transportation Research Part A: Policy and Practice 135, 244-263. DOI: 10.1016/j.tra.2020.01.025.

[25] Brumercikova, E., Bukova, B., Kondek, P. \& Drozdziel, P. (2017). Application of NFC Technology in Railway Passenger Transport by Introducing New Products. Communications Scientific Letters of the University of Zilina 19(2), 32-35. ISSN 1335-4205.

[26] Jensen, L.W., Schmidt, M. \& Nielsen, O. A. (2020). Determination of infrastructure capacity in railway networks without the need for a fixed timetable. Transportation Research Part C: Emerging Technologies 119, Article no. 102751. DOI: 10.1016/j.trc.2020.102751.

[27] Popescu, M., Bitoleanu, A., Deaconu, I. \& Dobriceanu, M. (2016). Improvement of power quality and energy efficiency in Bucharest metro traction substations. In 17th IEEE International Power Electronics and Motion Control Conference, PEMC 2016, 25-28 September 2016 (pp. 906-911). Varna, Bulgaria. DOI: 10.1109/EPEPEMC.2016.7752114.

[28] Stopka, O., Chovancová, M. \& Kampf, R. (2017). Proposal for streamlining the railway infrastructure capacity on the specific track section in the context of establishing an integrated transport system. MATEC Web of Conferences 134, Article no. 00055. DOI: 10.1051/matecconf/201713400055.

[29] Nycz, D. (2017). Influence of selected design parameters of the composite-foam cover rail on the course of the TB11 crash test of a road safety barrier forming a horizontal concave arc. The Archives of Automotive Engineering - Archiwum Motoryzacji 76(2). DOI: 10.14669/AM.VOL76.ART5. 